\title{
Seasonality on Transplanting Monocropped Lettuce and Intercropping With Staked Summer Squash
}

\author{
Leonardo Diogo Ehle Dias \\ Empresa Mato-grossense de Pesquisa Assistência e Extensão Rural, Tangará da Serra, MT,
} Brazil

Jucimar Ferreira Neves

Universidade Federal da Grande Dourados, Dourados, MS, Brazil

Leandro Batista da Silva

Universidade do Estado de Mato Grosso Carlos Alberto Reyes Maldonado, Tangara da Serra, MT, Brazil

Franciely da Silva Ponce

Universidade Estadual Paulista Júlio de Mesquita Filho, Botucatu, SP, Brazil

Oscar Mitsuo Yamashita

Universidade do Estado de Mato Grosso Carlos Alberto Reyes Maldonado, Alta Floresta, MT, Brazil

\section{Rivanildo Dallacort}

Universidade do Estado de Mato Grosso Carlos Alberto Reyes Maldonado, Tangara da Serra, MT, Brazil

Santino Seabra Júnior

Universidade do Estado de Mato Grosso Carlos Alberto Reyes Maldonado, Nova Mutum, MT, Brazil

Received: July 7, 2020

doi:10.5296/jas.v8i4.17324
Accepted: Sep. 1, 2020

Published: Sep. 2, 2020

URL: https://doi.org/10.5296/jas.v8i4.17324 


\section{Abstract}

Lettuce and summer squash are two important vegetables cultivated in peri-urban areas the cities in Mato Grosso State, Brazil. Their intercropping can increase the efficiency of the use of the area and the seasonality of harvest. This study aimed to evaluate the performance of lettuce (Lactuca sativa) and summer squash (Cucurbita moschata) in a conventional crop system and intercropped with different lettuce transplant period. These being the result of mono-cropping systems and intercropped lettuce with staked summer squash in six transplanting seasons of the lettuce and the monocropping of the trailing summer squash. The simultaneous transplantation of the two species provided the best performance of the lettuce. Summer squash production per plant did not differ between cropping systems; however, increased productivity was obtained with intercropping due to the higher density of plants. All the periods of inter-cropping establishment showed positive rates of land-use efficiency. For the summer squash production, intercropping systems provide better yield; however, the system hampers the development and production of lettuce.

Keywords: Lactuca sativa, Cucurbita moschata, production system, staked cultivation, efficient land use

\section{Introduction}

The horticulture generates some environmental impacts due to heavy handling and exposure of the soil, irrigation, intensive pesticides and fertilizers management. Alternatively, to reduce in the impact, it is essential to make rational use of natural resources and agricultural inputs, adhering and generating new technologies that supply the growing demand for food and reduce damage to the environment in the long-dates. A practice that stands out in this context is the intercropping cultivation of plants, which promotes better use of the soil and profitability by area (Cecílio Filho et al., 2010).

Compared to conventional farming agriculture, intercropping has several advantages, such as better ground cover due to higher plant density, a fact which reduces the incidence of weeds and increases protection against erosion (Mueller et al., 2004), provides better use of labour, water, land, fertilizers and other inputs (Silva et al., 2008), increase production by area and reduced installation costs of the main crop (Cecílio Filho et al., 2010), diversification of products harvested and marketed, higher profitability to the producer, and that a species can maximize the production of the other (Ohse et al., 2012).

The efficiency of intercropping depends directly on the cropping system and the species involved, with the necessity of complementation between these (Ouma and Jeruto, 2010), being that their yields are very dependent on the coexistence period in intercropping, determined by the establishment time of the intercropping, the plant architecture (Rezende et al., 2005a).

Lettuce (Lactuca sativa) is the most essential economic leafy vegetable in the world, occupying in 2018 1.227.358 hectares of cultivated area, with a production of 26.866.577 tons. It is suitable for regions with high temperatures and light, primarily when practices are used that minimize the effects of heat and excessive light (Neves et al. 2016). Pumpkins, squash, zucchinis and gourds, whose total production in 2018 was 27,449,481 tons from an 
area of 2,078,450 hectares (FAO-FAOSTAT, 2019). These species are produced mainly by family farmers in small areas close by urban centres in Brazil.

Several studies have shown positive effects on the intercropping of lettuce with other vegetables, showing agronomic viability. As an example, some studies confirmed the potential for intercropping lettuce and cucumber (Silva et al., 2008); lettuce and onion (Paula et al., 2009; Haan and Vasseur, 2014); lettuce and marcela (Mota et al., 2011); lettuce and broccoli (Ohse et al., 2012), beans, okra, lettuce and pumpkin (Hadidi et al., 2011), corn and pumpkin (Mandumbu and Caravina, 2012), broccoli and lettuce (Yildirim and Turan, 2013) and lettuce and cucumber (Ribas et al., 2020).

The inter-cropping between lettuce and summer squash stands out, due to the efficient use of the area, in this system the pumpkin occupies the vertical space, reducing competition between species and reducing the direct incidence of solar radiation on lettuce at certain times of the day, similarly to what occurs in consortium with tutored cucumber (Silva et al., 2008).

The choice of component cultures and the establishment of the period between them is fundamental in intercropping success and coexistence between species can influence the productivity of the same (Cecílio Filho et al., 2008; Ouma and Jeruto, 2010).

This study was designed to evaluate the performance of lettuce (Lactuca sativa) and summer squash (Cucurbita moschata) in a conventional crop system and intercropped with different lettuce transplant period.

\section{Material and Methods}

This study was carried out at experimental area in Mato Grosso State University (UNEMAT),

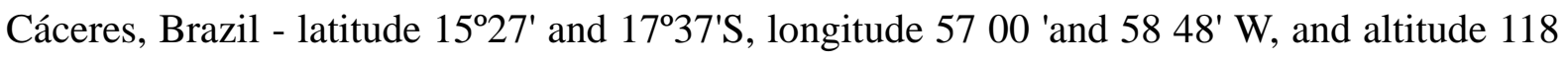
$\mathrm{m}$. The Köppen's climate classification of the area is tropical (Aw), with an average annual rainfall of $1,355 \mathrm{~mm}$ and high average temperature-average of $26{ }^{\circ} \mathrm{C}$ and can reach temperatures up to $41{ }^{\circ} \mathrm{C}$ (Neves et al., 2011).

The experimental design was a randomized complete block design with 13 treatments, five replications. Treatments 1-12 resulted from the combination of lettuce transplanting period, being 0, 10, 20, 30, 40 and 50 days after emergence (DAE) of summer squash in intercropping and lettuce mono-crop to isolate the possible effect of the season planting factor, another summer squash treatment in conventional crop system (ground). At the same time, intercropping was conducted by staking in the spaces between beds. Therefore, we obtained a factorial $2 \times 6+1$.

For lettuce, the experimental units consisted of 20 plants, with a total area of $2.16 \mathrm{~m}^{2}(1.2 \mathrm{~m} \mathrm{x}$ $1.8 \mathrm{~m}$ ), where the useful area for evaluation was $0.45 \mathrm{~m}^{2}$, with six central plants. For summer squash ten plants we used, using intercropping and mono-cropping with a total area of 12.6 and $44 \mathrm{~m}^{2}$ respectively, where all the plants were evaluated. The area was divided into two, intercropping and lettuce monocrop were installed and summer squash monocrop.

The lettuce crops and cucumber were planted and cover fertilized as recommended by Trani and Raij (1997). For lettuce, the fertilization was calculated for every $1.0 \mathrm{~m}$ of bedding and summer squash per pit, considering a total of $1250 \mathrm{ha}^{-1}$ pits. 
The top fertilization for the lettuce was performed at 7, 12, 17 and 22 days after transplantation with $20 \mathrm{~kg} \mathrm{ha}^{-1}$ of $\mathrm{N}$ during the first two fertilizations and $30 \mathrm{~kg} \mathrm{ha}^{-1}$ of $\mathrm{N}$ during the last two, totalling $100 \mathrm{~kg} \mathrm{ha}^{-1}$ of $\mathrm{N}$ (urea). For the summer squash, there were five cover fertilization, the first on the fifteenth day after planting and the others every seven days with $20 \mathrm{~kg} \mathrm{ha}^{-1} \mathrm{~N}$ (urea) and $12 \mathrm{~kg} \mathrm{ha}^{-1}$ of $\mathrm{K}_{2} \mathrm{O}$ (potassium chloride).

Cultivation lines to lettuce were directed by north/south face to promote shading, $1.2 \mathrm{~m}$ wide, $15 \mathrm{~m}$ long and $0.2 \mathrm{~m}$ in height for growing lettuce. For the summer squash 100 pits were made, five lines with ten pits for each bed. In the intercropping system, the summer squash was grown between the flowerbeds from a distance of $0.3 \mathrm{~m}$, being staked in an espalier system using a flat wire fence arranged every $0.3 \mathrm{~m}$ and up to $1.8 \mathrm{~m}$ high.

"Vera" lettuce cultivar and summer squash "Menina Brasileira Precoce" was used. The lettuce seeds were sown in experimental plots to every 10 days in polystyrene trays type 128/6, using commercial substrate Plant Max HT®, being kept under a greenhouse covered with agricultural plastic film (polyethylene) and shade cloth (sombrite) 30\%. The transplant was realized 25 days after when the seedlings had about four true leaves at $0,10,20,30,40$ and 50 DAE (days after emergence) of the summer squash on the beds with the spacing of 0.3 $\mathrm{x} 0.3 \mathrm{~m}$. For the summer squash, direct seeding was performed using two seeds per pit. Two weeks after planting the paring took place, keeping only one plant per pit. The spacing used was $2 \times 2 \mathrm{~m}$ in the monocrop (ground) and $1.8 \times 0.7 \mathrm{~m}$ in the shaded plants (staked), totalling a stand of 2,500 and 7,940 ha $^{-1}$ plants, respectively.

Suspended micro-sprinklers did the irrigation of the intercrop, and the lettuce mono-crop and the summer squash mono-crop was done by drip. The weed control was performed by manual cultivation.

The lettuce harvest was performed 40 days after transplantation. We evaluated the diameter of the plant, number of leaves, stem length, total fresh mass with which productivity was estimated $\left(\mathrm{t} \mathrm{ha}^{-1}\right)$, commercial fresh commercial mass (production), and dry matter in obtained by the commercial fresh $\left(\mathrm{g} \mathrm{ha}^{-1}\right)$ plants and dry matter obtained by dehydration of fresh commercial mass $\left(\mathrm{g} \mathrm{ha}^{-1}\right)$ mass dehydration.

For the cultivation of the summer squash, the standard used for commercial harvesting of fruits was approximately $0.2 \mathrm{~m}$ in length (Filgueira, 2013). We evaluated the fresh weight of total fruits (commercial + non-commercial) and commercial with which the yields were estimated. The yield per plant was also evaluated, the total number of fruits and marketable, the length and mass of marketable fruits.

To evaluate the efficiency of the intercropped system, the Efficient Land Use index was used (ELU), proposed by Willey (1979), which is defined as the relative area of land under monocropping conditions that is required to provide the yields achieved in intercropping. It is known that ELU $=$ intercropped lettuce productivity/mono-cropped lettuce productivity+inter-cropped summer squash productivity/mono-cropped summer squash productivity. 
Thus, intercropping is considered adequate when the ELU values are greater than 1. In a supposed case where intercropping obtained an ELU value of 1.2, this means that a $20 \%$ increase in a mono-cropped area will be necessary to get the same performance achieved in inter-cropping.

The data analysis was performed via variance analysis and means were compared via Tukey's test, and the summer squash by the T-test, both with $(\mathrm{p} \leq 0.05)$ using the Assistat ${ }^{\mathrm{TM}}$ software version 7.7 beta (PT) (Silva and Azevedo, 2016).

\section{Results and Discussion}

There was a significant interaction for all lettuce parameters evaluated between farming systems and transplantation period compared to the day of summer squash emergence (Table 1 and 2). There were no significant differences between the cropping systems for productivity, production and biomass accumulation of lettuce when transplanted on the summer squash emergence ( 0 days), obtaining between 21 to $23 \mathrm{t} \mathrm{ha}^{-1}$. However, for all other periods, the intercropped systems presented lower results than mono-crops for the same parameters, producing very small plants ranging from 24 to $65 \mathrm{~g}$ (Table 1). The failure for lettuce intercropping system, possibly due to strong intense shade provided by growth summer squash habit.

For stem length, the lettuce grown using intercropping was higher than in monocrop, when transplanted on the emergence of the summer squash (Table 2). When transplanted 10 DAE, no significant difference was observed. As for the later periods, intercropping showed lower stem growth.

The stem growth is directly related to the growth, and development and yield of the lettuce, so the fact that greater higher stem growth $(11.3$ and $10.2 \mathrm{~cm})$ was observed in the transplanted plants on the emergence and initial development of summer squash in intercropping, 0 and 10 day, respectively. This happens because summer squash didn't still show competition by light and lead to lettuce development without competitive interference (Stagnari et al., 2015).

The lettuce plants in the intercropped system that were transplanted 20 DAE after summer squash had shorter lenghtlength stems due to the fact thatsince its development is much less than mono-cropping, this difference was $36 \%$. This due to shade avoidance by summer squash that changes phenologicalphonological effects as tropism that leads to increase stem lenghtlength corroborating to higher visual effects. Stavridou et al. (2012) also observed growth inhibition of lettuce grown in consortium with larger plants, in this case, broccoli. 
Table 1. Split of interactions between times and cropping systems for productivity $\left(\mathrm{t} \mathrm{ha}^{-1}\right)$, production $\left(\mathrm{g} \mathrm{plant}^{-1}\right)$ and dry mass of lettuce $\left(\mathrm{g} \mathrm{plant}^{-1}\right)$ in Cáceres, Mato Grosso, Brazil, 2012

\begin{tabular}{|c|c|c|c|c|c|c|}
\hline \multirow[b]{2}{*}{ Times } & \multicolumn{6}{|c|}{ 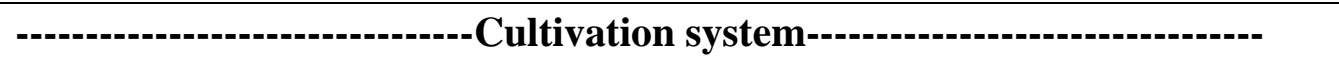 } \\
\hline & \multicolumn{2}{|c|}{-----Produtivity'1----- } & $\begin{array}{l}\text { Intercrop } \\
\text {-----Prod }\end{array}$ & $\begin{array}{l}\text { Monocrop } \\
\text { tion'----- }\end{array}$ & \multicolumn{2}{|c|}{----Dry mass ${ }^{1}-----$} \\
\hline 0 day & $23.1 \mathrm{aA}$ & $21.4 \mathrm{de} \mathrm{A}$ & $207.9 \mathrm{aA}$ & $192.5 \mathrm{deA}$ & $8.6 \mathrm{aA}$ & $9.8 \mathrm{cdA}$ \\
\hline 10 days & $16.9 \mathrm{aB}$ & $29.2 \mathrm{bcA}$ & $152.3 \mathrm{aB}$ & $262.5 \mathrm{bcA}$ & $6.5 \mathrm{aB}$ & $11.7 \mathrm{bcA}$ \\
\hline 20 days & $5.6 \mathrm{bB}$ & $17.8 \mathrm{eA}$ & $50.0 \mathrm{bB}$ & $160.2 \mathrm{eA}$ & $3.4 \mathrm{bB}$ & $9.3 \mathrm{dA}$ \\
\hline 30 days & $7.2 \mathrm{bB}$ & $37.4 \mathrm{aA}$ & $64.8 \mathrm{bB}$ & $336.2 \mathrm{aA}$ & $3.6 \mathrm{bB}$ & $13.9 \mathrm{abA}$ \\
\hline 40 days & $4.2 \mathrm{bB}$ & $34.8 \mathrm{abA}$ & $37.9 \mathrm{bB}$ & $313.5 \mathrm{abA}$ & $2.5 \mathrm{bB}$ & $14.1 \mathrm{aA}$ \\
\hline 50 days & $2.7 \mathrm{bB}$ & $25.2 \mathrm{cdA}$ & $24.2 \mathrm{bB}$ & $227.1 \mathrm{cdA}$ & $2.0 \mathrm{bB}$ & $14.4 \mathrm{aA}$ \\
\hline CV (\%) & 18.25 & & 18.25 & & 13.11 & \\
\hline DMS times & 7.3 & & 66.0 & & 2.3 & \\
\hline $\begin{array}{l}\text { DMS } \\
\text { system }\end{array}$ & 4.9 & & 44.4 & & 1.6 & \\
\hline F times & $15.9^{* *}$ & & $15.9^{* *}$ & & $7.4^{* *}$ & \\
\hline F systems & $319.2^{* *}$ & & $319.1^{* *}$ & & $605.9^{* *}$ & \\
\hline $\begin{array}{l}\text { F time. x F } \\
\text { syst. }\end{array}$ & $48.3^{* *}$ & & $26.6^{* *}$ & & $32.2^{* *}$ & \\
\hline
\end{tabular}

${ }^{1}$ Means followed by different lowercase letters in columns, and different capitals in lines differ by Tukey test at $5 \%$ probability. ${ }^{* *}$ Significant at $1 \%$ probability by $\mathrm{F}$ test

Similar results were obtained by Rezende et al. (2005b) and Ohse et al. (2012), who found an increase in the lettuce stem length when shaded by tomato and broccoli, respectively. Luz et al. (2009) and Diamante et al. (2013) also had higher lettuce stem lengths when cultivated under thermal reflector screens and shading, compared with the open field and other studies involving the growth of plants in height when shaded.

The leaf number and the diameter lettuce plants were not affected by the cropping system in the first two lettuce transplant period (0 and $10 \mathrm{DAE}$ of summer squash), ranging from 20 to 23 leaves and 36.4 to $38.5 \mathrm{~cm}$ in diameter (Table 2). But nevertheless, for the other periods, there was a significant difference, and mono-cropping values were higher, reducing the number of leaves from 38 to $62 \%$ and the diameter from 19 to $38 \%$. The lettuce yield reduction and plant development was affected by limitations on growth in the intercropping system. The shade of cucumber plants reduced the passage of solar radiation and consequently, the photosynthetic activity, in lettuce in the intercropping system (Ribas et al., 2020).

The lettuce transplanted in monoculture or intercropped (0 and 10 DAE of pumpkin), did not differ in productivity and, production and dry matter. In the other transplant times, lettuce obtained lower or similar means for the consortium, in relation toconcerning monoculture (Table 1). In general, the later the transplant, the lower the yield of intercropped lettuce, reducing productivity by 42 to $89 \%$. 
Table 2. Split of interactions between times and cropping systems for stem length $(\mathrm{cm})$, a number of leaves and lettuce plant diameter $(\mathrm{cm})$ transplanted at different times in monocropping and intercropping with summer squash staked in Cáceres, Mato Grosso, Brazil, 2012

\begin{tabular}{|c|c|c|c|c|c|c|}
\hline \multirow{3}{*}{ Times } & \multicolumn{6}{|c|}{ 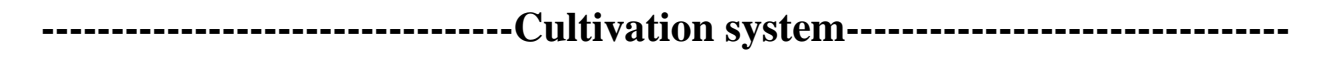 } \\
\hline & Intercrop & Monocrop & Intercrop & Monocrop & Intercrop & Monocrop \\
\hline & \multicolumn{2}{|c|}{ Stem length ${ }^{1}$} & \multicolumn{2}{|c|}{ Number of leaves ${ }^{1}$} & \multicolumn{2}{|c|}{ Plant diameter ${ }^{1}$} \\
\hline 0 day & $11.3 \mathrm{aA}$ & $8.7 \mathrm{aB}$ & $23.5 \mathrm{aA}$ & $23.1 \mathrm{aA}$ & $36.8 \mathrm{aA}$ & $37.7 \mathrm{aA}$ \\
\hline 10 days & $10.2 \mathrm{aA}$ & $9.3 \mathrm{aA}$ & $20 \mathrm{bA}$ & $21.6 \mathrm{aA}$ & $36.4 \mathrm{aA}$ & $38.5 \mathrm{aA}$ \\
\hline 20 days & $3.2 \mathrm{bA}$ & $5.0 \mathrm{bA}$ & $10 \mathrm{cB}$ & $16.2 \mathrm{bA}$ & $28.1 \mathrm{bB}$ & $34.8 \mathrm{aA}$ \\
\hline 30 days & $5.6 \mathrm{bB}$ & $8.1 \mathrm{abA}$ & $10.9 \mathrm{cB}$ & $22 \mathrm{aA}$ & $26.8 \mathrm{bB}$ & $37.8 \mathrm{aA}$ \\
\hline 40 days & $4.4 \mathrm{bB}$ & $8.7 \mathrm{aA}$ & $9.8 \mathrm{cB}$ & $24.1 \mathrm{aA}$ & $23.8 \mathrm{bcB}$ & $37.4 \mathrm{aA}$ \\
\hline 50 days & $4.6 \mathrm{bB}$ & $8.0 \mathrm{abA}$ & $9.2 \mathrm{cB}$ & $24.2 \mathrm{aA}$ & $21.8 \mathrm{cB}$ & $35.0 \mathrm{aA}$ \\
\hline $\mathrm{CV}(\%)$ & 21.49 & & 8.8 & & 6.60 & \\
\hline DMS times & 3.3 & & 3.4 & & 24.6 & \\
\hline $\begin{array}{l}\text { DMS } \\
\text { systems }\end{array}$ & 2.2 & & 2.7 & & 3.1 & \\
\hline F times & $16.8^{* * *}$ & & $41.7^{\text {** }}$ & & $22.9^{* *}$ & \\
\hline F systems & $10.3^{* *}$ & & $307.0^{* *}$ & & $159.5^{* *}$ & \\
\hline $\begin{array}{l}\mathrm{F} \text { time. } \times \mathrm{F} \\
\text { syst. }\end{array}$ & $\mathrm{F} \quad 5.7^{* *}$ & & $34.1^{\text {** }}$ & & $13.0^{* *}$ & \\
\hline
\end{tabular}

${ }^{1}$ Means followed by different lowercase letters in columns and different capitals in lines differ by Tukey test at $5 \%$ probability. ${ }^{* *}$ Significant at $1 \%$ probability by $\mathrm{F}$ test.

The lower yield as the transplant of intercropped lettuce is delayed, is mainly due to interspecific competition for light, since the intercrop is established among species of different cycles, architectures, sizes, speed and direction of growth and employment area. This also occurred with broccoli (Rezende et al., 2005b and 2010) or tomato (Ohse et al., 2012), highlighting the importance of consortium studies between species, because that inter cropping main issue is inter specific competition.

The division of the incident solar radiation on plants in intercropping is determined by the height and shape of the plants and the efficiency of interception and absorption. The shading caused by the highest culture reduces the amount of solar radiation to the lower culture. Since solar radiation is incipient as to affect the development of the second second-seeded or transplanted culture, choosing the best arrangement and planting or transplanting is crucial for a goodn excellent performance of intercropped species (Teixeira et al., 2005). Thus, studies should be carried out showing the inter-specific competition between species, determining the period in which they must be intercropped.

Therefore, the intercropped lettuce with staked summer squash in the spaces between beds is only recommended for lettuce when it is transplanted on the emergence of summer squash or $10 \mathrm{DAE}$, and this is because, during the cycle of the lettuce, summer squash development did 
not interfere significantly in the availability of radiation required for the metabolism of lettuce plants to synthesize the required amount of Photosynthate for healthy development.

Another possible cause for the limited development of intercropped lettuce with staked summer squash, is the occurrence of allelopathic effects of the summer squash over the lettuce, inhibiting their growth. According to Jabran and Farooq (2012), typically several types of interaction between neighbouring plants of various species besides the pumpkin have been described as a form of competition and allelopathy to other plants, insects and weeds.

For the number of leaves, stem length and diameter of plants, lettuce showed proportional behaviour to the observed for the fresh weight per plant production, since these parameters are directly interconnected (Table 2). Moreover, the average number of lettuce leaves per plant was higher in the first season of lettuce transplant, intermediate for lettuce transplanted at $10 \mathrm{DAE}$ of summer squash and lower for the other times that do not differ from each other.

The lettuce plants transplanted on the day of emergence and 10 DAE of summer squash do not show any difference in stem length, but these were higher than the plants transplanted in any time (Table 2). Greater diameter of lettuce plants was obtained in times greater 0 and 10 DAE with about $37 \mathrm{~cm}$, which in turn was greater than 20 and 50 DAE (22 to $28 \mathrm{~cm}$ ).

In mono-crop, the lettuce transplant times influenced the productivity parameters, production, dry weight, number of leaves and stem length, not only interfering in the diameter of the plants that showed no difference between the transplant times, ranging from 35 to $38 \mathrm{~cm}$ (Table 1 and 2).

Productivity and lettuce production in monocropping were higher when transplanted 30 and 40 DAE of summer squash (Table 1). The lowest yield $\left(5.6 \mathrm{t} \mathrm{ha}^{-1}\right)$ and yield per plant $(50 \mathrm{~g}$ plant $^{-1}$ ) were obtained when lettuce was transplanted on the 20 DAE. These yields are consistent with the patterns obtained in the research with smooth lettuce by Diamante et al. (2013).

The yield obtained in the various transplantation times was unexpected since the management was the same among them. This result is attributed to the differences in the microclimate in the cultivation environment provided by the summer squash development during the lettuce cycles.

During the execution of the experiment, there were regular periods, with average temperatures ranging between 24 and $30{ }^{\circ} \mathrm{C}$ (Figure 1). Quick periods of sudden drops in temperature with the minimum reaching 8 to $15{ }^{\circ} \mathrm{C}$ and a period of continued temperature rise in the final phase of the experiment, with average and maximum exceeding 30 to $37^{\circ} \mathrm{C}$, respectively.

According to Puiatti and Finger (2005), lettuce tolerates temperatures ranging from 4 to $27{ }^{\circ} \mathrm{C}$, outside that range its development is impaired. Therefore, the variation in productivity and lettuce production at different periods of transplantation under mono-cropping is explained by temperature variation during the periods comprising the cycle at each period transplantation, considering that, the highest productivity and production occurred at 30 and 
$40 \mathrm{DAE}$, coinciding with the period of lower average temperature during the experiment, ranging from 16.8 to $28.2{ }^{\circ} \mathrm{C}$, and with two sudden drops in temperature where the maximum did not exceed the $24{ }^{\circ} \mathrm{C}$ during the field phase of the lettuce.

Except for lettuce transplanted 20 DAE of summer squash, times with lower yields and production (0 and 50 DAE) coincided with periods of higher temperatures (Figure 1).

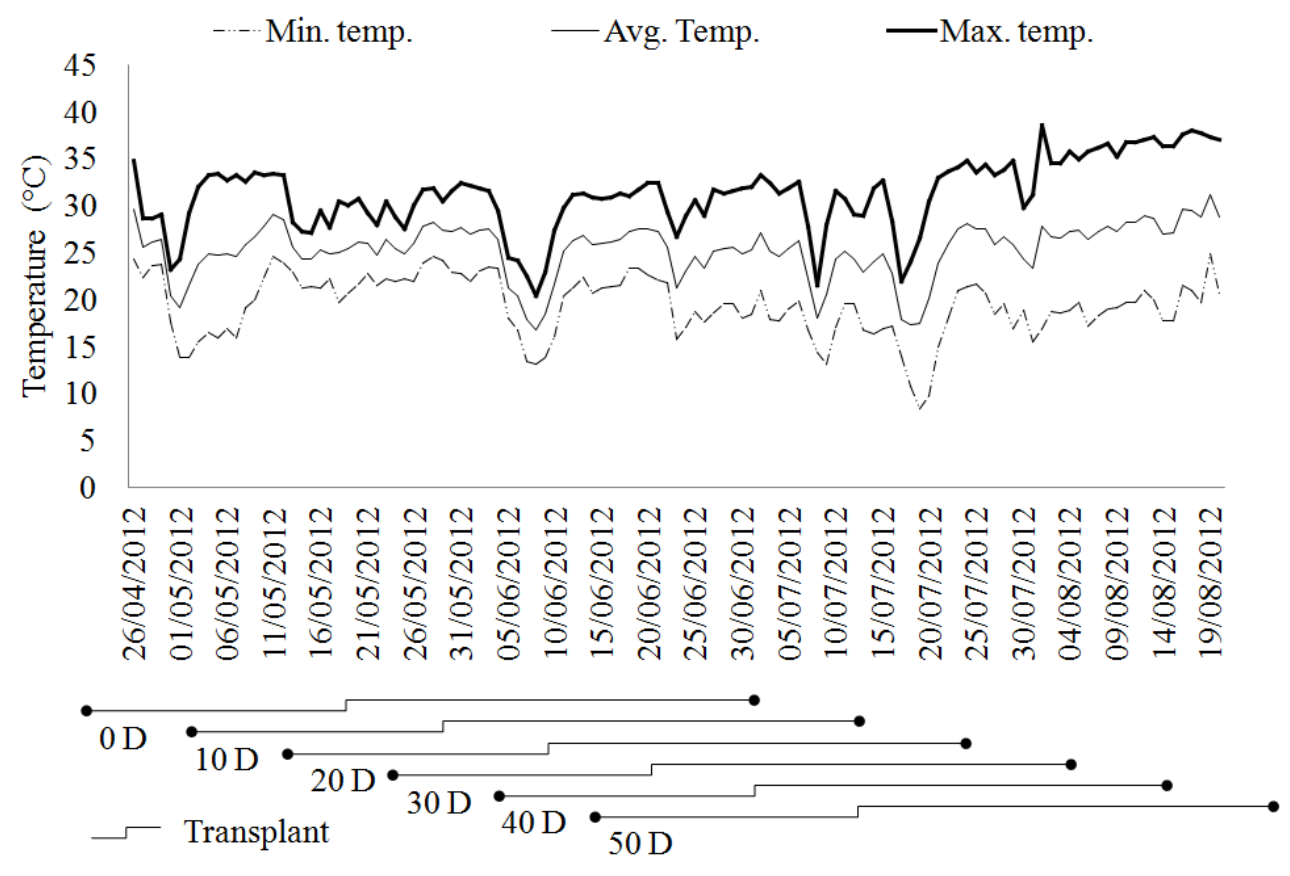

Figure 1. Maximum $\left({ }^{\circ} \mathrm{C}\right)$, average $\left({ }^{\circ} \mathrm{C}\right)$ and minimum $\left({ }^{\circ} \mathrm{C}\right)$ air temperature, in the period between 26/04/2012 and 20/09/2012. Data adapted from INMET (2012) for Cáceres, Mato

Grosso, Brazil, 2012. Times of lettuce cultivation, seedling and field phase

For summer squash, total and marketable fruit yield was higher in the intercropping system with lettuce, with an increase in productivity of $64 \%$ under staking (Table 3 ). The superiority of staked summer squash is related to the highest number of plants per hectare since the yield per plant was not influenced by the cultivation system. The conventional system for summer squash production type "Menina Brasileira" is related to $2 \times 2 \mathrm{~m}$ spacing (Filgueira, 2013). By using this spacing a stand of 2,500 plants $\mathrm{ha}^{-1}$ is presented, whereas in intercropping cultivation under staking a spacing of $1.8 \times 0.7 \mathrm{~m}$ a stand of 7,940 plants ha- ${ }^{-1}$. Therefore, the yield was related to each stand on the adopted system.

Productivity in intercropping under staking was slightly below the estimated productivity in the study on the summer squash production for different ages of seedlings, with "Sandy" hybrid summer squash, got $26.3 \mathrm{t} \mathrm{ha}^{-1}$ (Salata et al., 2011). This results may be associated with the yield of cultivars in the growing region. The occurrence of flower abortion or rise of male flowers due to the high temperatures recorded during the experiment (Figure 1). According to Oliniki et al. (2011) and (Fontes and Puiatti, 2005) temperature below to $18{ }^{\circ} \mathrm{C}$ and higher than $25^{\circ} \mathrm{C}$ can lead to reducing the yield of summer squash provide a significant reduction in the occurrence of female flowers and consequently the production of cucurbits. 
Table 3. Total productivity (TP), commercial productivity (CP), production, the total number of fruits (TNF), number of commercial fruits (NCF), average fruit mass (AFM) and fruit length (FL) of staked grown summer squash in intercropping with lettuce and ground in monocropping in Cáceres, Mato Grosso, Brazil, 2012

\begin{tabular}{|c|c|c|c|c|c|c|c|}
\hline $\begin{array}{c}\text { Cultivatio } \\
\text { n system }\end{array}$ & $\begin{array}{c}\mathbf{T P}^{\mathbf{1}} \\
\left(\mathbf{t} \mathbf{h a}^{-1}\right)\end{array}$ & $\begin{array}{c}\mathbf{C P}^{1} \\
(\mathbf{t} \\
\left.\mathbf{h}^{-1}\right)\end{array}$ & $\begin{array}{c}\text { Productio } \\
n^{1} \\
\left(\text { g plant }^{-1}\right)\end{array}$ & $\mathrm{TNF}^{1}$ & $\mathrm{NCF}^{1}$ & $\begin{array}{c}\mathbf{A F M}^{1} \\
(\mathbf{g} \\
\left.\text { fruit }^{-1}\right)\end{array}$ & $\begin{array}{c}\mathbf{F L}^{1} \\
(\mathbf{c m} \\
\left.\text { fruit }^{-1}\right)\end{array}$ \\
\hline Intercrop & $23.4 \mathrm{a}$ & $20.2 \mathrm{a}$ & 2550.6 & 9.2 & $6.4 \mathrm{a}$ & $403.6 \mathrm{~b}$ & 21.9 \\
\hline Monocrop & $8.4 \mathrm{~b}$ & $7.2 \mathrm{~b}$ & 2873.5 & 9.2 & $6.5 \mathrm{a}$ & $447.1 \mathrm{a}$ & 21.1 \\
\hline $\mathrm{CV}(\%)$ & 14.4 & 17.04 & 12.86 & 15.83 & 14.71 & 4.39 & 5.09 \\
\hline DMS & 6.3 & 6.5 & 969.6 & 4.0 & 2.6 & 51.9 & 3.0 \\
\hline $\mathrm{F}$ & $107.6^{* *}$ & $78.1^{* *}$ & $2.1^{\mathrm{ns}}$ & $0.0^{\mathrm{ns}}$ & $0.0^{\mathrm{ns}}$ & $13.6^{*}$ & $1.4^{\mathrm{ns}}$ \\
\hline
\end{tabular}

${ }^{1}$ Averages followed by different letters in columns differ by t-test, at $5 \%$ probability. ** significant at $1 \%$ probability by $\mathrm{F}$ test. ${ }^{*}$ significant at $5 \%$ probability by $\mathrm{F}$ test. ${ }^{\mathrm{ns}} \mathrm{Not}$ significant by $\mathrm{F}$ test

Total production, commercially marketable fruits and the average length of fruit were not influenced by summer squash cultivation system (Table 3). Non-interference was observed by lettuce in the production of the summer squash. This is explained by the architecture of this species, and the vertical driving of the summer squash made it develop and produce just as well in intercropping as in mono-cropping under the creeping system. Similar results were found in inter-cropping pepper and lettuce (Rezende et al., 2006), tomato and lettuce (Rezende et al., 2005a; Cecílio Filho et al., 2008) and between cucumber and lettuce (Rezende et al. 2010) where the production was not influenced by the presence of lettuce.

The similarity found between the average length of fruits values in intercropping and ground farming was due to harvest fruit timing according to consumer preference, $20 \mathrm{~cm}$ (Table 3). Therefore, average fruit weight was observed a significant difference between farming systems, and the mono-cropping system provided the production of more massive fruits (447 g fruit $\left.^{-1}\right)$.

Another essential aspect that should be emphasized is that the fruits harvested from staked plants had been completely clean and green belly free. This observation is explained by non-ground contact with soil (Filgueira, 2013). The fact that the fruits are picked above of the soil become more easy harvest handling, post-harvest practice and marketable fruits.

In all intercropping establishment times, rates of efficient land use yielded values above 1.0 (Figure 2). The occurrence of efficient land use presented rate values higher than 1 . This value shows intercrop advantage of summer squash and lettuce concerning monocrops. As an advantage, more and more food produced in the same unit area, inferring that in these conditions there was a better use of resources available in the cultivation environment. The efficient land use rate was influenced by lettuce transplantation times concerning the emergence of summer squash. When lettuce transplant was later, the value of efficient land use was less than one showing that the season later transplant change lettuce development. 


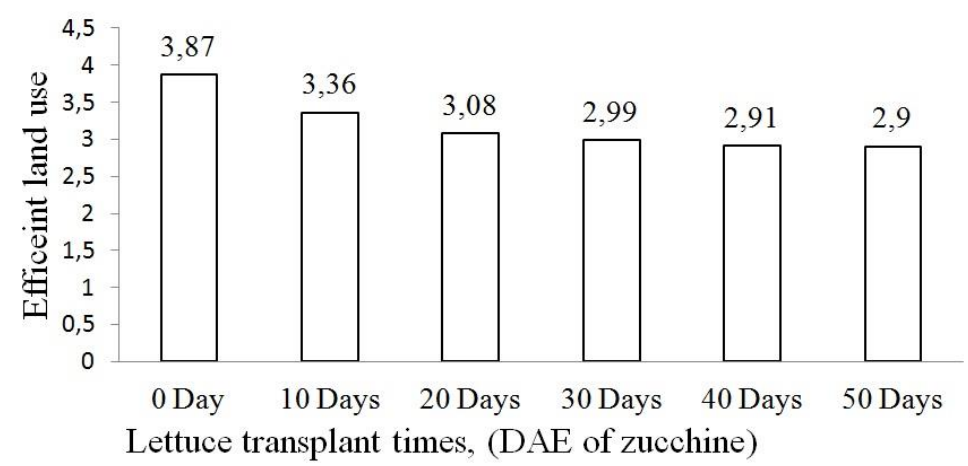

Figure 2. Values of Efficient Land Use related to lettuce transplantation times in relation to the DAE of summer squash in Cáceres, Mato Grosso, Brazil, 2012

Even though the development of the lettuce was impaired in intercropping (20, 30, 40 and 50 days) with the staked summer squash, high efficient land use values were obtained, it was because high summer squash yield in intercropping systems, provided by the density at planting and larger stand of plants per unit area.

The efficiency of vegetable intercropping systems defined through the efficient land use rate, the rate being equivalent of area or reason of area was also observed by Hadidi et al. (2011), Mota et al. (2011) Ohse et al. (2012) and Yildirim and Turan (2013) in their studies of various arrangements of vegetable intercropping.

Based on these results, there was no damage in the production of summer squash in intercropping with lettuce, but the lettuce production was impaired as it increased the difference of days between the emergences of summer squash with the transplanting of lettuce. Therefore, the study of intercropping staked summer squash with other species of agronomic interest is suggested. In addition, the possibility of cultivating cut zucchini can be considered, especially for producers with small areas of cultivation, allowing for efficient use of the available area.

\section{Conclusion}

The intercropping of lettuce with summer squash is only recommended for lettuce when transplanted on the emergence day or $10 \mathrm{DAE}$ after the summer squash.

The summer squash presents higher yield in an inter-cropping system with lettuce.

The Efficient Land Use rate demonstrates intercropping's efficiency by lettuce summer squash.

\section{References}

Cecílio Filho, A. B, Rezende, B. L. A., \& Costa, C. C. (2010). Economic analysis of the intercropping of lettuce and tomato in different seasons under protected cultivation. Horticultura Brasileira, 28, 326-336. https://doi.org/10.1590/S0102-05362010000300015 
Cecílio Filho, A. B., Rezende, B. L. A., Barbosa, J. C., Feltrim, A. L., Silva, G. S., \& Grangeiro, L. C. (2008). Interaction between lettuce and tomato plants, in intercropping cultivation, established at different times, under protected cultivation. Horticultura Brasileira, 26, 158-164. https://doi.org/10.1590/S0102-05362008000200006

Diamante, M. S., Seabra Júnior, S., Inagaki, A. M., Silva, M. B., \& Dallacort, R. (2013). Production and resistance to bolting of loose-leaf lettuce grown in different environments. $\begin{array}{llll}\text { Revista Ciência Agronômica, } & \text { 133-140. }\end{array}$ https://doi.org/10.1590/S1806-66902013000100017

FAOSTAT (FAO Statistics Database). (2019). Retrieved from http://www.fao.org/faostat/en/\#data/QC. Access in: 12 may 2020.

Filgueira, F. A. R. (2013). Novo manual de olericultura (3rd ed). In: Cucurbitáceas: Pepino e Outras Hortaliças Fruto. Viçosa, Lush: UFV, p. 335-370.

Fontes, P. C. R., \& Puiatti, M. (2005). Cultura do pepino. In: Fontes PCR. Olericultura: Teoria e Prática. Viçosa, UFV. p. 439-455.

Haan, J. L., \& Vasseur, L. (2014). Above and below ground interactions in monoculture and intercropping of Onion and Lettuce in Greenhouse Conditions. American Journal of Plant Science, 5, 3319-3327. https://doi.org/10.4236/ajps.2014.521347

Hadidi, N., Sharaiha, R., \& Al-Debei, H. (2011). Effect of Intercropping on the performance of some summer vegetable of grown under different row arrangements. Lucrari Stiintifice, 54, $11-17$.

Jabran, K., \& Farooq, K. (2012). Implications of Potential Allelopathic Crops in Systems. In: Cheema ZA \& Wahid MFA (Ed). Springer. p. 349-385. https://doi.org/10.1007/978-3-642-30595-5_15

Luz, A. O., Souza, S. B. S., \& Nascimento, A. S. (2009). Resistance to tasseling of lettuce genotypes in cultivation environments. Agrarian, 2, 71-82.

Mota H. M., Vieira M. C., \& Araújo C. (2011). Growth and yield of lettuce and marcela (Achyrocline satureioides) in single-cultivar and intercropping. Acta Scientiarum. Agronomy, 33, 269-273. https://doi.org/10.4025/actasciagron.v33i2.4426

Mueller, S., Durigan, J. C., Kreuz, C. L. \& Banzato, D. A. (2004). Garlic-Carrot Intercropping Times Under Three Weed Management Systems in Caçador-SC. Planta Daninha, 22, 507-516. https://doi.org/10.1590/S0100-83582004000400004

Neves, J. F., Nodari, I. D. E., Seabra Júnior, S., Dias, L. D. E., Silva L. B., \& Dallacort, R. (2016). Production of american lettuce cultivars under different environments in tropical $\begin{array}{lllll}\text { conditions. } & \text { Revista } & \text { Agro@mbiente. } & 10, & 130-136 .\end{array}$ https://doi.org/10.18227/1982-8470ragro.v10i2.3200

Neves, S. M. S., Nunes, M. C. M., \& Neves, R. J. (2011). Characterization of climatic conditions from Cáceres/MT, Brazil, from 1971 to 2009: subsidy for agricultural activities 
and tourist city Boletim Goiano de Geografia, 31, 55-68. https://doi.org/10.5216/bgg.v31i2.16845

Ohse, S., Rezende, B. L. A., Silveira, L. S., Otto, R. F., \& Cortez, M. G. (2012). Agronomic feasibility of Broccoli and lettuce intercropping estabilished in different growing period. Idesia, 30, 29-37. https://doi.org/10.4067/S0718-34292012000200004

Ouma, G., \& Jeruto, P. (2010). Sustainable horticultural crop production through intercropping: The case of fruits and vegetable crops: A review. Agriculture and Biology Journal of North America, 1, 1098-1105. https://doi.org/10.5251/abjna.2010.1.5.1098.1105

Paula, P. D., Guerra, J. G. M., Ribeiro, R. L. D., Cesar, M. N. Z., Guedes, R. E., \& Polidoro, J. C. (2009). Agronomic viability of onion and lettuce intercropped in the organic cultivation $\begin{array}{llll}\text { system. } & \text { Horticultura } & \text { Brasileira } & 27,\end{array}$ https://doi.org/10.1590/S0102-05362009000200014

Puiatti, M., \& Finger, F. L. (2005). Fatores climáticos. In: Fontes PCR. Olericultura: teoria e prática. Rio Branco, Suprema Gráfica e Editora, p.17-38.

Rezende, B. L. A, Cecílio Filho, A. B., Martins, M. I. E. G., Costa, C. C., \& Feltrim, A. L. (2005b). Viabilidade econômica das culturas de pimentão, repolho, alface, rabanete e rúcula em cultivo consorciado, na primavera-verão, Jaboticabal, Estado de São Paulo. Informações Econômicas, 35, 22-37.

Rezende, B. L. A., Cecilio Filho, A. B., Conato, G. H. D., \& Martins, M. I. E. G. (2005a). Economic analysis of the intercropping of lettuce $\mathrm{x}$ tomato in protected cultivation at Jaboticabal (SP). Cientifica, 3, 42-49. https://doi.org/10.15361/1984-5529.2005v33n1p42-49

Rezende, B. L. A., Cecílio Filho, A. B., Feltrim, A. L., Costa, C. C., \& Barbosa, J. C. (2006). Viabilidade da consorciação de pimentão com repolho, rúcula, alface e rabanete. Horticultura Brasileira, 24, 36-41. https://doi.org/10.1590/S0102-05362006000100008

Rezende, B. L. A., Cecilio Filho, A. B., Pôrto, D. R. Q., Barros Junior, A. P., Silva, G. S., Barbosa, J. C., \& Feltrim, A. L. (2010). Consórcios de alface crespa e pepino em função da população do pepino e época de cultivo. Interciencia, 35, 374-379.

Ribas, R. G. T., Cecilio Filho, A. B., Dutra, A. F., Barbos, J. C., \& Rolim, G. S. (2020). Land equivalent ratio in the intercropping of cucumber with lettuce as a function of cucumber population density. Agriculture, 10, 1-13. https://doi.org/10.3390/agriculture 10030088

Salata, A. C., Higuti, A. R. O., Godoy, A. R., Magro, F. O., \& Cardoso, A. I. I. (2011). Squash production as a function of seedling age. Ciência e Agrotecnologia, 35, 511-515. https://doi.org/10.1590/S1413-70542011000300011

Silva, F. A. S., \& Azevedo, C. A. V. (2016). The Assistat Software Version 7.7 and its use in the analysis of Experimental data. African Journal Agriculture Research, 11(39), 3733-3740. https://doi.org/10.5897/AJAR2016.11522

Silva, Q. S., Rezende, B. L. A., Cecílio Filho, A. B., Barros Júnior, A. P., Martins, M. I. E. G, 


\section{Macrothink

\& Porto, D. R. Q. (2008). Economic viability of the crisphead lettuce culture in monoculture and intercropping with cucumber. Ciência e Agrotecnologia, 32, 1516-1523. https://doi.org/10.1590/S1413-70542008000500024

Stagnari, F., Galieni, A., \& Pisante, M. (2015). Shading and nitrogen management affect quality, safety and yield of greenhouse-grown leaf lettuce. Scientia Horticuturae, 192, 70-79. https://doi.org/10.1016/j.scienta.2015.05.003

Teixeira, I. R., Mota, J. H., \& Silva, A. G. (2005). Intercrop of Vegetables. Semina: Ciências Agrárias, 26, 507-514. https://doi.org/10.5433/1679-0359.2005v26n4p507

Trani, P. E., \& Raij, B. (1997). Hortaliças. In: Raij B, Cantarella H, Quaggio JÁ, Furlani ÂMC. Recomendações de adubação e calagem para o estado de São Paulo. 2 ed. Campinas, IAC, p.157-185.

Willey, R. W. (1979). Intercropping: its importance and research needs: Part 1. Competition and yield advantages. Field Crop Abstracts, 32, 1-10.

Yildirim, E., \& Turan, M. (2013). Growth yield and mineral content of Broccoli intercropped with Lettuce. The Journal of Animal \& Plant Science, 23, 919-922.

\section{Copyright Disclaimer}

Copyright for this article is retained by the author(s), with first publication rights granted to the journal.

This is an open-access article distributed under the terms and conditions of the Creative Commons Attribution license (http://creativecommons.org/licenses/by/4.0/). 